perforation. ${ }^{3}$ Perhaps, significantly (more so had the number of cases been greater), all six were women with an average age of 45 . Our patient was also a woman, who was 52 .

Our patient presented with rectal bleeding at defaecation. No such case has been reported. Possibly the bleeding may have been due to haemorrhoids, but against this no bleeding has occurred since resection of the diverticulum, despite her piles still being present and untreated. The barium enema findings strongly suggested the presence of a polyp and this led to erroneous diagnosis and difficulties at laparotomy. The confusion seems best explained by the partially barium-filled diverticulum overlying the barium-filled colon on the radiographs giving the appearance of "a lobulated lesion, probably a polyp." This phenomenon should be borne in mind by all those searching for elusive polyps.

We thank Mr R E C Collins for helpful discussion and advice and Miss Susan Stickells for typing the manuscript.

1 Morson, B C, and Dawson, I M, Gastro-intestinal Pathology, p 435. Philadelphia, Lippincott, 1972.

${ }^{2}$ Hughes, L E, Gut, 1969, 10, 336.

${ }^{3}$ Chugntal, S Q, and Ackerman, N B, American fournal of Surgery, 1974, 127, 508 .

(Accepted 21 Fune 1978)

Kent and Canterbury Hospital, Canterbury, Kent

J M RIBCHESTER, MB, BS, senior house officer, general surgery

A WARD, FRCS, FRACS, registrar, general surgery cause was presumably atrophic thyroiditis, despite the absence of thyroid autoantibodies, and he was not taking any known goitrogen. The subsequent development of thyrotoxicosis is also well documented. Thyrotoxicosis medicamentosa is discounted by the raised 6-hour ${ }^{131} \mathrm{I}$ uptake and failure of this to suppress with T3. The physical findings and the result of the thyroid scan exclude toxic adenoma and toxic multinodular goitre.

Together with the positive thyroid stimulating immunoglobulins these features are compatible with the diagnosis of thyrotoxic Graves's disease after primary hypothyroidism. Reported cases of this have been inadequately documented. The mechanisms by which this patient developed the above sequence of events is not clear. It was apparent that his thyroid was incapable initially of maintaining him euthyroid despite increased pituitary output of TSH, and yet two years later was responding excessively to the stimulus of thyroid stimulating immunoglobulins. Possibly his hypothyroidism was due to blocking of the TSH receptor by biologically inactive thyroid stimulating antibody, and that later this antibody became capable of stimulating the thyroid.

We acknowledge the contribution of Dr D Hurrell, the patient's general practitioner, and thank Dr B R Smith for carrying out the thyroid stimulating immunoglobulin assay.

${ }^{1}$ Mukhtar, E D, et al, Lancet, 1975, 1, 713.

2 Goolden, A W G, Davidson, M, and Hoffenberg, R, Lancet, 1971, 2, 268

${ }^{3}$ James, K W, Lancet, 1971, 2, 156

(Accepted 5 fuly 1978)

Freeman Hospital, Newcastle upon Tyne NE7 7DN

S OLCZAK, BSC, MRCP, SHO in medicine (present address: Brompton Hospital, London)

A J MCCULLOCH, BSC, MRCP, registrar in medicine

F CLARK, FRCP, consultant physician

\section{Thyrotoxic Graves's disease after primary hypothyroidism}

We report a case of thyrotoxicosis following primary hypothyroidism in a 61-year-old man.

\section{Case report}

A retired local government officer presented in January 1976 with a sixmonth history of loss of energy and deepening voice. In 1957 he had had a total colectomy for ulcerative colitis. There was no family history of autoimmune disease. He was not taking any medication and weighed $78 \mathrm{~kg}$. $\mathrm{He}$ looked hypothyroid and his thyroid gland was impalpable,.

Investigations showed: protein-bound iodine (PBI) $180 \mathrm{nmol} / 1(2 \cdot 3 \mu \mathrm{g}$ $100 \mathrm{ml})(310-630(3 \cdot 9-8.0 \mu \mathrm{g} / / 100 \mathrm{ml}))$; Thyopac-3 $121.5(92-117)$; TSH $23.7 \mathrm{mU} / 1(<6)$; thyroid antibodies negative. Treatment with L-thyroxine was started in February 1976. By April he was clinically and biochemically euthyroid on $150 \mu \mathrm{g}$, PBI $460 \mathrm{nmol} / 1(5.8 \mu \mathrm{g} / 100 \mathrm{ml})$, and TSH $1.6 \mathrm{mU} / \mathrm{l}$. He was discharged from the clinic, but one year later complained of weight loss and shakiness. He weighed $71 \mathrm{~kg}$. His general practitioner reduced and eventually stopped the thyroxine in November 1977, when his weight was down to $67 \mathrm{~kg}$. He was referred back to the clinic, where he was found to have lid retraction, tremor, and a small diffuse goitre. Thyroid function tests showed: serum thyroxine $149 \mathrm{nmol} / 1(11.6 \mu \mathrm{g} / 100 \mathrm{ml}),(60-140 \mathrm{nmol} / \mathrm{l}$ $(4 \cdot 7-10 \cdot 9 \mu \mathrm{g} / 100 \mathrm{ml}))$; serum tri-iodothyronine $4.6 \mathrm{nmol} / 1 \quad(3.0 \mathrm{ng} / \mathrm{ml})$ $(1 \cdot 2-3.0 \mathrm{nmol} / 1(0 \cdot 78-1.9 \mathrm{ng} / \mathrm{ml}))$; TSH values at 0 and 20 minutes after administration of $200 \mu \mathrm{g}$ TRH were 1.5 and $1.3 \mathrm{mU} / 1$, respectively. Thyroid stimulating immunoglobulin index 41 (normal > 75), ${ }^{1}$ but thyroid autoantibodies remained negative. ${ }^{131} \mathrm{I}$ uptake was $63 \%$ at six hours (thyrotoxicosis likely above $55 \%$ ), with no suppression of uptake ( $74 \%$ at six hours) after ad.ninistration of T3. A thyroid scan showed minimal general thyroid enlargement with uniform distribution of isotope.

He was started on treatment with carbimazole and, on a blocking dose with maintenance L-thyroxine, he is euthyroid and has gained weight to $73 \mathrm{~kg}$.

\section{Comment}

In 1971 four cases were reported of thyrotoxicosis occurring during treatment of suspected primary hypothyroidism..$^{2}$ In three cases the diagnosis of primary hypothyroidism was based on clinical findings and a raised serum cholesterol concentration. In the other case the diagnosis was made on the basis of a low PBI concentration only.

In our patient the diagnosis of primary hypothyroidism was clearly established by the low PBI, raised Thyopac-3, and raised TSH. The

\section{Long-term tri- and tetra-cyclic antidepressants, myocardial contractility, and cardiac rhythm}

Changes of the ECG revert to normal after prolonged administration of tri- and tetra-cyclic antidepressants (TCA), ${ }^{1}$ but little is known about the long-term effect of TCA on myocardial contractility. Significant arrhythmias and sudden death have been reported particularly in patients taking toxic doses of TCA, ${ }^{2}$ but only limited information is available on their effect in therapeutic doses. ${ }^{2} \mathrm{We}$ therefore investigated the influence of TCA on cardiac rhythm and myocardial contractility after prolonged administration.

\section{Patients, methods, and results}

Systolic time intervals (STI) and blood pressure were determined in five women aged $61 \pm 13$ years. The first tracing (A) was obtained three weeks after starting treatment and was repeated after $74.6 \pm 1.8$ months (B). The following antidepressants were used alone or in combination: maprotiline, amitriptyline, trimeprimine, imipramine, desipramine, and clomipramine. In two patients STI were recorded one year after stopping treatment, which had lasted for $35.5 \pm 4.9$ months. STI were recorded as described by Weissler ${ }^{3}$ In 18 patients $8 \mathrm{~h}$-daytime-Holter monitoring was performed during treatment. The patients were divided into three groups. In group 1 the first Holter tracing was obtained before and the second during treatment, whereas in group 2 the second ECG was taken four weeks after stopping treatment. In group 3 only one Holter recording was obtained (during treatment).

$S T I$-We found a significant further prolongation of pre-ejection period index $\left(\mathrm{PEP}_{\mathrm{c}}\right.$ ) from $132 \cdot 4 \pm 4 \cdot 7 \mathrm{~ms}(\mathrm{~A})$ to $144 \cdot 1 \pm 4.5 \mathrm{~ms}(\mathrm{~B})$. PEP/LVET (left ventricular ejection time) increased from $0.375 \pm 0.032$ (A) to $0.421 \pm$ 0.030 (B) (fig). In two patients who had been taking TCA for $36 \pm 4.9$ months, PEP decreased from $135 \cdot 2+9 \cdot 2$ (C) to $125 \cdot 3+6.5 \mathrm{~ms} 11.5$ month after treatment had been discontinued (D). The values for PEP/LVET were $0.412 \pm 0.042$ (C) and $0.356 \pm 0.040$ (D) respectively (figure). There were no significant changes of blood pressure between $A$ and $B$ and between $\mathrm{C}$ and $\mathrm{D}$.

Holter monitoring-4/10 patients in groups 1 and 2 had no arrhythmias 